\title{
RESILIENSI ANAK YANG BERKONFLIK DENGAN HUKUM: REFLEKSI IMPLEMENTASI UU. NO.11 TAHUN 2012 MENGENAI PROSES DIVERSI
}

\author{
Nailatin Fauziyah, \\ Suryanto, Yusti Probowati Rahayu \\ Jl. Airlangga 4-6 Surabaya| Universitas Airlangga| \\ nailatin.fauziyah@uinsby.ac.id
}

\begin{abstract}
Settlement of child criminal cases using the restorative justice approach and diversion in accordance with Law No. 11 of 2012 is an important breakthrough in the development of criminal law processes in Indonesia. At the conceptual level, the implementation of the process takes into consideration the fulfillment of children's rights and has a concern for the child's future. To achieve the future the child must have the resilience to deal with difficult situations throughout his life journey. Likewise, children who are in conflict with the law, on the other hand they are perpetrators of crime and on the other hand they are victims of the surrounding social system. The results of this study indicate that Children in conflict with the law $(\mathrm{ABH})$ who are resilient tend to get support from various parties so that they can get through difficult situations and face the future with confidence, but conversely with $\mathrm{ABH}$ who are not resilient. The results of this study are important notes to reflect back the implementation of Law No. I I/20 I 2 on restorative justice and diversion, because the diversion process undertaken by $\mathrm{ABH}$ does not differentiate their resilience levels. It is the strength of the protective factor that affects the differences in the resilience of $\mathrm{ABH}$ who undergo legal proceedings through diversion.

Keywords: Resilience, Children in conflict with the law, Law No. I I of 2012
\end{abstract}

Abstrak Penyelesaian perkara pidana anak dengan pendekatan keadilan restorative dan diversi sesuai dengan UU No. I I Tahun 2012 merupakan terobosan penting dalam perkembangan proses hukum pidana anak di Indonesia. Pada tataran konseptual, pelaksanaan proses tersebut sangat mempertimbangkan pemenuhan hak-hak anak dan memiliki keberpihakan 
terhadap masa depan anak. Untuk mencapai masa depan anak harus memiliki ketangguhan (resiliensi) untuk menghadapi situasi-situasi sulit sepanjang perjalanan hidupnya. Demikian pula anak yang berkonflik dengan hokum, yang disisi lain mereka adalah pelaku tindak pidana dan disisi yang lain mereka adalah korban dari system social di sekitarnya. Hasil penelitian ini menunjukkan bahwa $\mathrm{ABH}$ yang resilien cenderung mendapatkan dukungan dari berbagai pihak sehingga mereka bias melewati situasi sulit yang dihadapi dan menatap masa depan dengan percaya diri, namun sebaliknya pada $\mathrm{ABH}$ yang tidak resilien. Hasil penelitian ini menjadi catatan penting untuk merefleksikan kembali implementasi UU No. I I Tahun 20 I 2 mengenai keadilan restorative dan diversi, karena proses diversi yang dijalani oleh $\mathrm{ABH}$ tidak membedakan tingkat resiliensi mereka. Kuatnya factor protektiflah yang mempengaruhi perbedaan resiliensi $\mathrm{ABH}$ yang menjalani proses hukumnya melalui diversi.

Kata Kunci: Resiliensi, Anak yang berkonflik dengan hukum, UU No. I I Tahun 2012

\section{Pendahuluan}

Kasus anak yang berhadapan dengan hukum $(\mathrm{ABH})$ merupakan persoalan yang krusial di Indonesia. Laporan tahunan KPAI (Komisi Perlindungan Anak Indonesia) tahun 2018 menunjukkan bahwa perkembangan empat tahun terakhir mengenai pengaduan kasus perlindungan anak berjumlah 19.843 kasus. Pada tahun 2015 kasus perlindungan anak berjumlah 4.309 kasus, tahun 2016 berjumlah 4.622 kasus, tahun 2017 berjumlah 4.579 kasus, dan tahun 2018 mencapai 4.885 kasus. Dari jumlah kasus pengaduan yang masuk ke KPAI, kasus anak yang berhadapan dengan hukum $(\mathrm{ABH})$ menunjukkan prosentase yang paling besar, yaitu $29 \%$ atau 5.372 kasus. Pada kasus $\mathrm{ABH}$, perkembangan di Indonesia dari tahun ke tahun mengalami peningkatan sebagaimana yang terjadi empat tahun terakkhir ini. Pada tahun 2015 jumlah pengaduan kasus ABH mencapai 1.221 anak, tahun 2016 terdapat 1.314 anak, tahun 2017 terdapat 1.403, dan tahun 2018 terdapat 1.434 anak $^{1}$.

\footnotetext{
I www.kpai.co.id
} 
Anak menurut Undang-undang adalah seseorang yang belum berusia 18 (delapan belas) tahun, termasuk anak yang masih dalam kandungan ${ }^{2}$. Anak yang berhadapan dengan hukum adalah anak yang berkonflik dengan hukum, anak yang menjadi korban tindak pidana, dan anak yang menjadi saksi tindak pidana. Anak yang berkonflik dengan hukum yang selanjutnya disebut anak adalah anak yang telah berumur 12 (dua belas) tahun, tetapi belum berumur 18 (delapan belas) tahun yang diduga melakukan tindak pidana ${ }^{3}$.

Anak yang terlibat konflik dengan hukum bukanlah perilaku yang berdiri sendiri. Perilaku tersebut di pengaruhi oleh berbagai aspek. Menurut Supeno, banyaknya anak-anak Indonesia yang terlibat tindak kenakalan lebih disebabkan karena mereka adalah korban dari faktor-faktor di luar dirinya. Faktor-faktor tersebut meliputi: Pertama, ada lingkungan sosial di sekitar anak yang keras, baik dalam bidang ekonomi, sosial, politik, budaya, dan sebagainya. Kedua, lingkungan sekolah yang formalistis dan cenderung dehumanisasi menjadikan relasi guru dan murid, murid dan murid kehilangan nilai-nilai insaninya. Ketiga, sikap orang tua yang semakin permisif terhadap ikatan nilai-nilai moral, serta intensitas komunikasi yang tidak lagi intens karena modernisasi dan profesionalisasi, yang menuntut individu menekuni keahliannya dan mengabdikan diri secara total kepada dunia kerja bila tidak ingin tersingkir dari persaingan jenjang karir. Keempat, hilangnya ruang public untuk ekspresi anak, seperti olahraga, seni teater, sastra, permainan kreatif, dan sebagainya sehingga mereka lebih melampiaskan kepada hal-hal yang destruktif, tidak terkendali, tindakan coba-coba, tindakan mencari perhatian, melampiaskan heroism di depan teman sebaya, dan sebagainya. Kelima, pengaruh media massa khususnya televisi yang luar biasa masuk dalam ruang privat dan mendoktrin ajaran-ajaran kekerasan melalui film, sinetron, reality show, tayangan berita, maupun tayangan-tayangan lainnya. Keenam, hilangnya tokoh panutan anak-anak remaja

\footnotetext{
2 UU No.23 Tahun 2002 Tentang Perlindungan Anak

${ }^{3}$ UU No. I I Tahun 2012 tentang Sistem Peradilan Pidana Anak
} 
sehingga mereka mancari tokoh panutan yang paling mudah diakses atau bahkan tidak memiliki panutan sama sekali ${ }^{4}$.

Hasil penelitian Astutik menunjukkan bahwa kenakalan pada anak berhadapan dengan hukum dapat disebabkan oleh pola asuh anak dalam keluarga dan/atau keluarga pengganti. Hal ini dapat dilihat dari kurangnya penanaman nilai dan norma, penerapan aturan yang tidak tepat, kurangnya kasih sayang atau cara memberikan kasih sayang yang salah dan tidak adanya figur orangtua yang dapat diteladani anak. Hal ini terjadi karena selain faktor kemiskinan orangtua atau orang tua pengganti, juga disebabkan kekurangtahuan orangtua atau orang tua pengganti tentang pengasuhan anak, dan pengaruh lingkungan sosial juga dapat memicu peningkatan kecenderungan menjadi pelaku tindak pidana ${ }^{5}$.

Anak-anak yang melanggar hukum atau melakukan tindak pidana, maka proses penyelesaiannya sesuai dengan peraturan perundangan-undangan yang berlaku. Perbedaaan pelaksanaan sistem peradilan anak antara UU No. 3 Tahun 1997 tentang peradilan anak dengan UU No.11 Tahun 2012 tentang sistem peradilan pidana anak. Pada UU peradilan anak, anak harus mengikuti proses persidangan sesuai dengan tahapan sistem peradilan yang ada yaitu tahap pra judikasi, tahap judikasi, dan tahap pasca-judikasi. Pada sistem peradilan pidana anak wajib mengutamakan pendekatan keadilan restorative dan proses diversi. Pendekatan tersebut bisa dilakukan di setiap tahapan. Diversi adalah pengalihan penyelesaian perkara Anak dari proses peradilan pidana ke proses di luar peradilan pidana, sedangkan Keadilan Restoratif adalah penyelesaian perkara tindak pidana dengan melibatkan pelaku, korban, keluarga pelaku/korban, dan pihak lain yang terkait untuk bersama-sama mencari penyelesaian

\footnotetext{
${ }^{4}$ Supeno, H., (2010)., Kriminalisasi Anak. Tawaran Gagasan Radikal Peradilan Anak Tanpa Pemidanaan., PT. Gramedia Pusaka Utama

${ }^{5}$ Astuti, M., (20 I I). Anak Berhadapan Dengan Hukum Ditinjau Dari Pola Asuhnya Dalam keluarga (Studi Kasus Di Provinsi Sumatera Barat, Daerah Istimewa Jogyakarta Dan Provinsi Nusa Tenggara Barat)., Jurnal Informasi Kajian Permasalahan Sosial Dan Usaha Kesejahteraan Sosial Vol. I6, No. 01, Januari - April 20I I
} 
yang adil dengan menekankan pemulihan kembali pada keadaan semula, dan bukan pembalasan (UU SPPA pasal 1). Diversi dilaksanakan dalam hal tindak pidana yang dilakukan bila diancam dengan pidana penjara di bawah 7 (tujuh) tahun; dan bukan merupakan pengulangan tindak pidana ${ }^{6}$.

Situasi-situasi yang dihadapi $\mathrm{ABH}$ dalam menjalani proses hukum merupakan situasi yang sangat sulit untuk anak seusianya. Usia anak-anak atau remaja merupakan usia dimana mereka fokus belajar dan bermain dengan teman sebaya. Tahap dimana anakanak membutuhkan perhatian, bimbingan, dan dukungan dari orang-orang dewasa di sekitarnya agar mampu mencapai cita-cita di masa depannya. Penyelesaian perkara anak dengan keadilan restoratif melalui diversi ini diharapkan memiliki keberpihakan pada masa depan anak. Anak-anak mampu tangguh (resilient) terhadap situsasi sulit yang dihadapi dan anak-anak berhasil mencapai masa depan yang lebih baik. Resiliensi (ketangguhan) anak merupakan hal penting yang harus diperhatikan agar anakanak yang berkonflik dengan hukum mampu melanjutkan hidupnya, meraih masa depannya, dan agar menjadi generasi yang berkualitas di kemudian hari.

Ann Masten mendefinisikan resiliensi merupakan ketahanan individu yang mengacu pada keberhasilan beradaptasi meski dalam situasi yang berisiko dan dalam kesulitan7, sedangkan menurut Reivich \& Shatte merupakan kemampuan untuk mengatasi dan beradaptasi terhadap kejadian yang berat atau masalah yang terjadi dalam kehidupan. Bertahan dalam keadaan tertekan, dan bahkan berhadapan dengan kesengsaraan (adversity) atau trauma yang dialami dalam kehidupannya ${ }^{8}$. Luthar, dkk mengatakan bahwa resiliensi lebih mengarah kepada sebuah proses dinamis yang meliputi adaptasi positif dalam menghadapi

\footnotetext{
${ }^{6}$ Undang-Undang RI Nomor I I Tahun 2012 tentang Sistem Peradilan Pidana Anak

7 Masten, A.S., 1994., Resilience In Individual Development: Successful Adaptation Despite Risk And Adversity. In M. Wang \& E. Gordon (Eds.), Risk and resilience in inner city America: challenges and prospects. (pp. 3-25). Hillsdale, NJ: Erlbaum.

${ }^{8}$ Reivich, K. \& Shatte,A., (2002)., The resilience faktor:Seven essential skills for overcoming life's inevitable obstacles. New York:Broadway Books
} 
persoalan yang signifikan. Dalam pengertian ini terkandung dua kondisi kritis dalam resiliensi, (1) keterbukaan terhadap gangguan yang signifikan atau permasalahan yang berat; dan (2) mencapai adaptasi yang positif meskipun menghadapi rintangan dalam rentang masa perkembangan'.

Penelitian ini mencoba merefleksikan kembali implementasi UU No.11 Tahun 2012 tentang Sistem Peradilan Pidana Anak berdasarkan asas diterapkannya proses diversi yaitu perlindungan; keadilan; non diskriminasi; kepentingan terbaik bagi anak; penghargaan terhadap pendapat anak; kelangsungan hidup dan tumbuh kembang anak; pembinaan dan pembimbingan anak; proporsional; perampasan kemerdekaan dan pemidanaan sebagai upaya terakhir; dan penghindaran pembalasan; mencapai perdamaian antara korban dan anak; menyelesaikan perkara anak di luar proses peradilan; menghindarkan anak dari perampasan kemerdekaan; mendorong masyarakat untuk berpartisipasi; dan menanamkan rasa tanggung jawab kepada anak. Resiliensi merupakan salah satu aspek psikologis yang mensupport tercapainya tujuan dari pelaksanaan proses diversi tersebut.

\section{Anak Dalam Perspektif Hukum Dan Psikologi}

Perbedaan dalam mendefinisikan anak antara perspektif hukum dan psikologi terkait dengan rentang usia. Peraturan perundangundangan di Indonesia memiliki ketentuan yang berbeda-beda dalam menentukan batasan anak. Hal ini nampaknya disesuaikan dengan kondisi dan situasi bagaimana peraturan tersebut dibuat. Beberapa peraturan perundang-undangan yang memuat tentang batasan usia kategori anak antara lain:

1. Undang-undang No.12 tahun 1948 mengenai Hukum Perburuhan. Anak dalam Hukum Perburuhan Pasal 1 (1) Undang-undang pokok perburuhan mendefinisikan anak adalah orang laki-laki atau perempuan berumur 14 tahun ke bawah.

\footnotetext{
${ }^{9}$ Luthar, S. S., Cicchetti, D., \& Becker, B., (2000)., The construct of resilience: A critical evaluation and guidelines for future work. Child Development, 7I, 543-562.
} 
2. Undang-undang No 1 tahun 1974 tentang Perkawinan, telah memberikan tiga kriteria usia, yang meliputi: a) Usia syarat kawin yaitu 19 tahun dan wanita 16 tahun, b) Usia ijin kawin dimana bagi mereka yang akan menikah dibawah usia 21 tahun harus ada ijin dari orang tua. c) Usia dewasa yaitu 18 tahun atau telah kawin. Penyimpangan atas hal tersebut hanya dapat dimintakan dispensasi kepada Pengadilan Negeri.

3. Undang-Undang Nomor 4 Tahun 1979 Tentang Kesejahteraan Anak dalam Pasal 1 ayat (2) undang-undang ini anak didefinisikan sebagai seseorang yang belum mencapai umur 21 (dua puluh satu) tahun dan belum pernah kawin.

4. Konvensi PBB (Perserikatan Bangsa Bangsa) Dalam Konvensi PBB yang di tanda tangani oleh Pemerintah Republik Indonesia tanggal 1990 di katakan batasan umur anak adalah di bawah umur 18 (delapan belas) tahun).

5. Undang-Undang Nomor 3 Tahun 1997 Tentang Pengadilan Anak, definisi anak adalah orang yang dalam perkara anak nakal telah berumur 8 (delapan) tahun, tetapi belum mencapai umur 18 (delapan belas) tahun dan belum pernah kawin (Pasal 1 ayat (1) ) Sedangkan dalam Pasal 4 ayat (1) Undang-undang ini menyebutkan bahwa batasan umur anak nakal yang dapat diajukan ke sidang anak adalah anak yang sekurang-kurangnya 8 (delapan) tahun tetapi belum mencapai umur 18 (delapan belas) tahun dan belum pernah kawin.

6. Undang-Undang Republik Indonesia No.23 Tahun 2002 tentang perlindungan anak pada bab 1 pasal 1 ayat 1 , yang menyatakan bahwa anak adalah seseorang yang belum berusia 18 tahun termasuk anak yang masih dalam kandungan.

Perspektif psikologi perkembangan batasan usia diklasifikasi dalam beberapa kategori. Hurlock (2011) mengklasifikasi usia berdasarkan tahapan perkembangan antara lain: Usia sebelum kelahiran (Prenatal); usia 0-2 minggu : orok (infancy); usia 2 minggu - 2 tahun : bayi (babyhood); usia 2-6 tahun: anak-anak awal (early childhood); usia 6-12 tahun: anak-anak akhir (late childhood); usia 1214 tahun: pubertas (puberty); usia 14-17 tahun: remaja awal (early 
adolescene); usia 17-21 tahun: remaja akhir (late adolescene); usia 21-40 tahun: dewasa awal (early adulthood); usia 40-60 tahun: setengah baya (middle age); dan 60 tahun ke atas: tua (senescene) ${ }^{10}$. Menurut Monk dkk, anak merupakan mahluk yang membutuhkan pemeliharaan, kasih sayang dan tempat bagi perkembangannya. Selain itu anak merupakan bagian dari keluarga, dan keluarga memberi kesempatan bagi anak untuk belajar tingkah laku yang penting untuk perkembangan yang cukup baik dalam kehidupan bersama ${ }^{11}$. Batasan usia anak menurut perspektif psikologi adalah usia 6-12 tahun, sedangkan dalam perspektif hukum adalah seseorang yang berusia sebelum 18 tahun. Hal ini berarti kategori anak menurut hukum, dapat berarti kategori remaja menurut kajian psikologi.

Batasan usia untuk remaja secara umum yang diberlakukan di Indonesia menurut Sarlito Wirawan Sarwono sebaiknya menggunakan batasan usia 11-24 tahun dan belum menikah. Hal ini dengan beberapa pertimbangan:

a. Usia 11 tahun merupakan usia dimana pada umumnya tandatanda seksual sekunder mulai nampak

b. Di banyak masyarakat Indonesia, usia 11 tahun sudah dianggap sebagai akil baligh, baik menurut adat maupun agama, sehingga masyarakat tidak lagi memperlakukan mereka sebagai anak-anak

c. Pada usia tersebut mulai ada tanda-tanda penyempurnaan perkembangan jiwa seperti tercapainya identitas diri (ego identity menurut Erik Erikson), tercapainya fase genital dari perkembangan psikoseksual (menurut Freud) dan tercapainya puncak perkembangan kognitif (menurut Piaget) maupun moral (menurut Kohlberg).

d. Batas 24 tahun merupakan batas maksimal, yaitu untuk memberi peluang bagi mereka yang sampai batas usia tersebut

\footnotetext{
${ }^{10}$ Hurlock, E. B. (20 I I). Psikologi Perkembangan Suatu Pendekatan Sepanjang Rentang Kehidupan, Edisi 5. Jakarta: Erlangga.

II Monk, F.J., Knoers, A.M.P., Haditono, S.R. (20I I). Psikologi Perkembangan. Pengantar dalam Berbagai Bagiannya. Jogjakarta: Gadjah MadaUniversity Press.
} 
masih menggantungkan diri pada orang tua, belum mempunyai hak-hak penuh sebagai orang dewasa, belum bisa memberikan pendapat sendiri dan sebagainya. Dengan perkataan lain orang-orang yang sampai batas usia 24 tahun belum dapat memenuhi persyaratan kedewasaan secara sosial maupun psikologis masih dapat dikategorikan remaja. Golongan ini cukup banyak terdapat di Indonesia, terutama dari kalangan masyarakat kelas menengah ke atas yang mempersyaratkan berbagai hal untuk mencapai kedewasaan.

e. Pada definisi di atas, status perkawinan sangat menentukan, karena arti perkawinan masih sangat penting di masyarakat kita secara menyeluruh. Seseorang yang sudah menikah, pada usia berapapun dianggap dan diperlakukan sebagai orang dewasa penuh, baik secara hukum maupun dalam kehidupan masyarakat dan keluarga. Oleh karena itu definisi remaja di sini dibatasi khusus untuk yang belum menikah ${ }^{12}$

Perbedaan batasan usia anak dalam perspektif hukum dan psikologi memang banyak diperdebatkan, Penelitian ini secara redaksi tetap menggunakan istilah anak pada penyebutan anak yang berkonflik dengan hukum, meskipun subyek penelitiannya secara psikologi lebih mengarah pada usia remaja. Redaksi ini menyesuaikan pada fokus penelitian yaitu anak yang berkonflik dengan hukum $(\mathrm{ABH})$. Istilah anak yang berkonflik dengan hukum mengacu pada perundang-udangan yang berlaku (UU No.23 Tahun 2002 tentang Perlindungan Anak).

Anak berhadapan dengan hukum yakni anak-anak yang terlibat dalam persoalan hukum. Anak-anak dalam kondisi demikian disebut dengan anak yang berkonflik dengan hukum (children in conflict with the law), yang dalam praktik hukum di negara Indonesia digunakan istilah Anak yang Berhadapan dengan Hukum, adapun anak yang berhadapan dengan hukum tersebut adalah mereka yang berhubungan dengan proses peradilan, dengan klasifikasi: 1) Anak sebagai saksi; 2) Anak sebagai korban; dan3) Anak sebagai pelaku.

${ }^{12}$ Sarwono, S. W. (20 I 2)., Psikologi Remaja. Edisi revisi I5. Jakarta: Raja Grafindo Pustaka, 
Anak berhadapan dengan hukum yang sebagai pelaku seringkali disebut juga sebagai juvenile delinquency. Juvenile berarti anak-anak; anak muda, sedangkan Deliquency artinya terabaikan/mengabaikan yang kemudian diperluas menjadi jahat, kriminal, pelanggar peraturan dan lain-lain. Dalam Kamus Besar Bahasa Indonesia, delikuensi diartikan sebagai tingkah laku yang menyalahi secara ringan norma dan hukum yang berlaku dalam suatu masyarakat. Suatu perbuatan dikatakan delinkuen apabila perbuatan-perbuatan tersebut bertentangan dengan norma yang ada dalam masyarakat dimana ia hidup atau suatu perbuatan yang anti sosial yang didalamnya terkandung unsure-unsur anti normative ${ }^{13}$. Menurut Kartini Kartono Juvenile Deliquency yaitu perilaku jahat/dursila, atau kejahatan/kenakalan anak-anak muda, merupakan gejala sakit (patologi) secara sosial pada anak-anak dan remaja yang disebabkan oleh suatu bentuk pengabaian sosial sehingga mereka itu mengembangkan bentuk pengabaian tingkah laku yang menyimpang ${ }^{14}$.

\section{Resiliensi Anak Yang Berkonflik Dengan Hukum}

Penyelesaian kasus pidana anak secara hukum dapat ditempuh melalui dua pendekatan hukum yaitu mengacu pada UU No.3 Tahun 1997 tentang Peradilan Anak dan UU No.11 Tahun 2012 tentang Sistem Peradilan Pidana Anak. Sistem Peradilan Pidana Anak wajib mengutamakan pendekatan keadilan restoratif (pasal 5). Keadilan restoratif adalah penyelesaian perkara tindak pidana dengan melibatkan pelaku, korban keluarga pelaku/korban dan pihak lain yang terkait untuk bersama-sama mencari penyelesaian yang adil dengan menekan pemulihan kembali pada keadaan semula dan bukan pembalasan (pasal 6). Keadilan restoratif yang dimaksud adalah kewajiban melaksanakan Diversi. Diversi merupakan pengalihan penyelesaian perkara anak dari proses peradilan pidana ke proses diluar peradilan pidana. Diversi berfungsi agar anak yang berhadapan dengan hukum tidak

\footnotetext{
${ }_{13}$ Sudarsono.,(1991)., Kenakalan Remaja., Jakarta: RinekaCipta

${ }^{14}$ Kartono, Kartini., (2003). Patologi Sosial 2. Kenakalan Remaja. Jakarta: PT Raja Grafindo Persada
} 
terstigmatisasi akibat proses peradilan yang harus dijalaninya. Penggunaan mekanisme diversi tersebut diberikan kepada para penegak hukum (polisi, jaksa, hakim, lembaga lainnya) dalam menangani pelanggar-pelanggar hukum yang melibatkan anak tanpa menggunakan pengadilan formal.

Tahapan-tahapan dalam hukum acara pidana meliputi: (1) Praajudikasi, yaitu tindakan aparat hukum untuk melakukan penyelidikan dan penyidikan sebelum perkara diajukan ke pengadilan. Tujuan dari tahap ini adalah untuk penyelesaian Berita Acara Pemeriksaan (BAP); (2) Ajudikasi, yaitu pemeriksaan di pengadilan, mulai dari penuntutan sampai putusan; (3) Pasca-ajudikasi, yaitu tahap setelah putusan pidana dijatuhkan oleh hakim, termasuk upaya hukum biasa dan luar biasa. ABH dalam penyelesaian proses hukumnya yang mengacu pada UU No.3 Tahun 1997 akan melalui semua tahapan tersebut, sedangkan bila mengacu pada UU No.11 Tahun 2012 dapat menempuh diversi di setiap tahapannya.

Penelitian ini melibatkan 4 (empat) anak yang berkonflik dengan hukum yang proses hukumnya melalui diversi sebagai partisipan. Rentang usia $14-17$ tahun dengan kasus pencurian dan penganiayaan. Proses diversi dilakukan pada tahap penyidikan di kepolisian. Pelaksanaan proses diversi melibatkan pihak keluarga pelaku, aparat penegak hukum, dan pihak keluarga korban. Metode penelitian yang dignakan dalam penelitian ini adalah kualitatif dengan jenis studi kasus. Penentuan identifikasi resilien atau tidak resilien nya $\mathrm{ABH}$ pada penelitian ini mengacu pada karakteristik resiliensi internal dari Kumpfer yang menyatakan bahwa individu yang resilien memiliki beberapa karakteristik internal personality yang meliputi: spiritual or motivational characteristics, Cognitive competencies, behavioral/social competencies, dan emotional stability and emotional management ${ }^{15}$.

\footnotetext{
${ }^{15}$ Kumpfer, K. L., (1999).,Factors and Processes Contributing to Resilience. In. The Resilience Framework Resilience and Development: Positive Life Adaptations, 1999. edited by Glantz and Johnson. Kluwer Academic/Pienum Publishers, New York,
} 
Ditinjau dari proses hukum dalam penyelesaian masalahnya, hasil penelitian menunjukkan bahwa terbentuknya resiliensi $\mathrm{ABH}$ tidak dipengaruhi oleh faktor proses hukum yang dijalani dalam menyelesaikan perkaranya. Pada subyek yang penyelesaian kasusnya melalui proses diversi, dua anak menunjukkan memiliki kemampuan untuk beradaptasi secara positif atau resilien dan dua anak menunjukkan tidak resilien atau kurang mampu beradaptasi secara positif pada situasi yang sulit. Proses terbentuknya resiliensi $\mathrm{ABH}$ yang proses hukumnya melalui proses diversi adalah diawali dengan adanya stressor (proses penangkapan dan diserahkan ke pihak yang berwajib untuk di proses secara hukum). Situasi tersebut merupakan situasi yang sulit dan menekan bagi $\mathrm{ABH}$ (fase stress), sehingga $\mathrm{ABH}$ merasa tidak berdaya atas situasi yang ada (fase deteriorating). Pada kondisi tersebut $\mathrm{ABH}$ mendapatkan dukungan dari faktor eksternal (eksternal protective) sepanjang perjalanan proses hukumnya (pra ajudikasi dan pasca ajudikasi). Faktor eksternal yang meliputi keluarga dan teman sebaya (mikro system), lembaga pendidikan, lembaga pemerintah, dan lembaga swadaya masyarakat (meso system). Dukungan yang diperoleh membuat $\mathrm{ABH}$ belajar mengembangkan perilaku adaptasi positif pada keadaan yang dihadapi dan secara perlahan pulih dari kondisi psikologis atas situasi yang menekan sebelumnya (fase adapting dan recovering), perkembangan selanjutnya $\mathrm{ABH}$ mampu beradaptasi secara positif dan mengembangkan diri lebih baik lagi (fase strengthening). Selain hal tersebut, terbentuknya resiliensi $\mathrm{ABH}$ ini juga dipengaruhi oleh latarbelakang keluarga dan pengalamanpengalaman positif yang diperoleh sepanjang waktu (chronosystem), misalnya kelekatan pada figur ibu, lingkungan rumah yang terorganisir, perilaku beragama keluarga yang baik, keterlibatan orang tua dalam pendidikan anak, pola pengasuhan authoritatif, dan iklim keluarga yang positif dengan tingkat perselisihan orang tua yang rendah. Latar belakang keluarga dan pengalamanpengalaman positif ini juga mempengaruhi terbentuknya karakter positif (internal protective faktor) yang menjadi modal awal yang mempengaruhi reslisiensi $\mathrm{ABH}$. 
Proses terbentuknya kerentanan atau tidak resiliennya $\mathrm{ABH}$ yang proses hukumnya melalui proses diversi, sebagaimana pada $\mathrm{ABH}$ yang resilien adalah diawali dengan adanya stressor (proses penangkapan dan diserahkan ke pihak yang berwajib untuk di proses secara hukum). Situasi tersebut merupakan situasi yang sulit dan menekan bagi $\mathrm{ABH}$ (fase stress), sehingga $\mathrm{ABH}$ merasa tidak berdaya atas situasi yang ada (fase deteriorating). Pada kondisi tersebut $\mathrm{ABH}$ kurang mendapatkan dukungan dari faktor eksternal (eksternal protective) sepanjang perjalanan proses hukumnya (pra ajudikasi dan pasca ajudikasi). Dukungan diperoleh hanya dari lembaga swadaya masyarakat yang bergerak dalam bidang perlindungan dan pendampingan anak. Pada saat proses diversi ada anggota keluarga yang datang, namun hal tersebut sebatas memenuhi panggilan aparat pemerintah. $\mathrm{ABH}$ cenderung mendapatkan banyak perlakuan yang tidak menyenangkan (faktor risiko) yang diperoleh dari keluarga, teman sebaya, dan tetangga (mikro system). Kondisi tersebut membuat ABH semakin merasa terpuruk dan tidak berdaya, serta kurang mampu mengembangkan adaptasi positif terhadap situasi yang ada. Selain hal itu, $\mathrm{ABH}$ menjadi tidak resilien karena dipengaruhi oleh oleh latarbelakang keluarga dan pengalaman-pengalaman negatif yang diperoleh sepanjang waktu (chronosystem), misalnya perceraian orang tua, family violence, phisical neglect, emotional neglect, pola asuh permisif, tinggal terpisah dari orang tua, physical abuse, dan emotional abuse. Latarbelakang keluarga dan pengalaman-pengalaman negatif ini juga mempengaruhi terbentuknya karakter negatif (internal risk factor) yang menjadi modal awal yang mempengaruhi reslisiensi atau tidaknya $\mathrm{ABH}$.

Hasil penelitian ini menemukan bahwa pada proses penyelesaian masalah $\mathrm{ABH}$ dengan diversi terdapat $\mathrm{ABH}$ yang resilien dan tidak resilien. Hal ini menunjukkan bahwa proses penyelesaian perkara anak melalui diversi tidak mempengaruhi terbentuknya resiliensi anak. Hal ini tidak sejalan dengan gerakan aktivis perlindungan anak yang mengatakan bahwa proses diversi adalah bentuk perlindungan terhadap hak-hak anak untuk 
mencapai masa depannya. Hasil penelitian ini menunjukkan bahwa terbentuknya resiliensi $\mathrm{ABH}$ dipengaruhi oleh kuatnya faktor protektif internal dan eksternal (ranah microsystem, mesosystem, dan chronosystem), bukan proses penyelesaian hukumnya. resiliensi menjadi faktor penting bagi $\mathrm{ABH}$ untuk mencapai keberhasilannya dimasa depan.

Dalam ilmu psikologi perkembangan manusia, resiliensi memiliki arti yang luas dan beragam, termasuk pemulihan dari pengalaman traumatis, mengatasi kelemahan untuk berhasil dalam hidup, dan menahan stres untuk berfungsi dengan baik dalam tugas-tugas kehidupan.Menurut McCubbin, resiliensi merupakan konstruk psikologi yang diajukan oleh para ahli behavioral dalam rangka usaha untuk mengetahui, mendefinisikan dan mengukur kapasitas individu untuk tetap bertahan dan berkembang pada kondisi yang menekan (adverse conditions) dan untuk mengetahui kemampuan individu untuk pulih kemabali (recovery) dari kondisi tertekan ${ }^{16}$. Sejalan dengan McCubbin, Grotberg menyatakan bahwa resiliensi adalah kapasitas individu untuk menghadapi, mengatasi, memperkuat diri, dan tetap melaksanakan perubahan sehubungan dengan ujian yang dialami ${ }^{17}$. Setiap Individu memiliki kapasitas untuk menjadi resilien. Sedangkan Reivich \& Shatte mendefinisikan resiliensi sebagai kemampuan untuk mengatasi dan beradaptasi terhadap kejadian yang berat atau masalah yang terjadi dalam kehidupan. Bertahan dalam keadaan tertekan, dan bahkan berhadapan dengan kesengsaraan (adversity) atau trauma yang dialami dalam kehidupannnya ${ }^{18}$. Namun Garmezy mengangap resiliensi adalah fungsi yang cukup berkelanjutan dari kemampuan yang berfungsi meskipun keadaan sulit ${ }^{19}$.

\footnotetext{
${ }^{16}$ McCubbin, L., (200I).,Challenges to the Definition of Resilience., American Psychological Association. Paper presented at the Annual Meeting of the American Psychological Association (I09th, San Francisco, CA, August24-28, 200 I).

${ }_{17}$ Grotberg, E.H. (1999). Countering Depression With the Five Building Blocks of Resilience. From: Grotberg, Edith. (1999). Countering depression with the five building blocks of resilience. Reaching Today's Youth 4(I, Fall): 66-72. http://resilnet.uiuc.edu/library/grotb99.html

${ }^{18}$ Reivich, K. \&Shatte,A., (2002)., The resilience faktor:Seven essential skills for overcoming life's inevitable obstacles. New York:Broadway Books

${ }^{19}$ Garmezy, N. (1993). Children in poverty: Resiliency despite risk. Psychiatry, 56( I), I27-I 36.
} 
Dalam kajian resliensi faktor-faktor resiliensi seringkali disebut sebagai faktor pelindung dan faktor resiko. Werner melihat bahwa banyak hal yang dapat menjadi faktor protektif bagi sesorang yang resilien ketika berhadapan dengan kondisi yang menekan. Dalam penelitiannya menemukan kualitas-kualitas individu yang dapat menjadi faktor protektif yang memungkinkan seseorang dapat mengatasi tekanan dalam kehidupan mereka yaitu antara lain kesehatan, sikap yang tenang (easygoing), kontrol emosi, kompetensi intelektual, internal locus of control, konsep diri yang positif, kemampuan perencanaan dan kualitas keimanan ${ }^{20}$. Dalam review Masten, dkk (1990) mengidentifikasi sejumlah faktor yang berhubungan dengan tingkat resiliensi seseorang antara lain, pola asuh dan perhatian orang tua, hubungan yang dekat dengan seseorang yang dapat dijadikan sandaran, kemampuan menyelesaikan masalah dan efikasi diri ${ }^{21}$.

Faktor protektif dapat dibagi menjadi dua kategoris yaitu internal faktor pelindung dan external protective factor. Pada kajian McCubbin internal faktor pelindung merupakan faktor pelindung yang bersumber dari individu seperti harga diri, efikasi diri, kemampuan mengatasi masalah, regulasi emosi dan optimisme. Sedangkan external faktor pelindung merupakan protektif faktor yang bersumber dari luar individu seperti dukungan keluarga dan lingkungan ${ }^{22}$. Sedangkan beberapa peneliti telah mengungkap tiga variable yang berperan sebagia faktor protektif yang mungkin menghalangi atau menghentikan pengaruh pengalaman buruk. Schoon \& Bynner menunjukan faktor-faktor tersebut:

\footnotetext{
20 Werner, E. E. (2005). What can we learn about resilience from largescale longitudinal studies? In S. Goldstein \& R. Brooks (Eds.), Handbook OfResiliencein Children (pp. 91 - 106). New York: Kluwer Academic Publishers.

${ }^{2}$ Masten, A. S., Best, K. M. \&Garmezy, N., (1990)., Resilience and development: Contributions from the study of children who overcome adversity. Development and Psychopathology, 2, 425444.

22 McCubbin, L., (200I).,Challenges to the Definition of Resilience., American Psychological Association. Paper presented at the Annual Meeting of the American Psychological Association (I09th, San Francisco, CA, August24-28, 200 I).
} 
a) Atribut individual : Anak-anak yang memiliki resiliensi berpenampilan lebih baik dalam tes-tes sekolah mereka, menunjukkan lebih sedikit problem perilaku yang menetap, dan memiliki banyak hobi serta lebih banyak melakukan kontak sosial dibandingkan kelompok anak yang peka. Anak-anak yang memiliki resiliensi menyukai sekolah, menunjukkan keyakinan kuat terhadap kemampuan internal mereka serta memiliki aspirasi yang tinggi.

b) Karakteristik keluarga, lingkungan keluarga yang stabil dan penuh dukungan, orang tua yang menunjukkan perhatian terhadap pendidikan anak-anaknya merupakan faktor yang memperkuat adaptasi positif anak

c) Aspek-aspek konteks sosial secara luas, termasuk guru, mentor atau pendamping. Faktor resikodan faktor pelindungberhubungan dan saling berpengaruh secara interaktif. Faktor protektif, khusunya menjadi penting ketika individu mengahadapi faktor berisiko ${ }^{23}$

Masten menyebutkan sekumpulan faktor aset dan faktor pelindung, yaitu : (1) Karakteristika individu; temperamen sosial dan adaptasi pada masa bayi, kemampuan kognitif dan keterampilan pemecahan masalah yang baik, Strategi regulasi emosi dan perilaku yang efektif, tampilan diri yang positif (selfconfidence, harga diri yang tinggi, self-efficacy), pandangan yang positif mengenai kehidupan (harapan), keyakinan dan rasa kebermaknaan hidup, karakteristik dihargai oleh masyarakat dan diri (bakat, rasa humor, daya tarik kepada orang lain). (2) Karakteristik keluarga, lingkungan rumah stabil dan mendukung, rendahnya tingkat perselisihan orang tua, hubungan dekat dengan pengasuh, gaya pengasuhan otoritatif (tinggi pada kehangatan, struktur/pemantauan, dan harapan), hubungan yang baik dengan saudara, saling mendukung antar anggota keluarga, orang tua terlibat dalam, pendidikan anak, orangtua memiliki kualitas

\footnotetext{
${ }^{23}$ Schoon, I. \& Bynner, J. (2003). Risk and resilience in the life course: Implications for interventions and sosial policies. Journal of Youth Studies, 6(I), 2I-3I.
} 
individu yang baik, sebagai pelindung bagi anak, kondisi sosial ekonomi yang baik, pendidikan post secondary dari orang tua, afiliasi keyakinan dan agama, (3) Karakteristik komunitas; kualitas lingkungan tinggi, lingkungan aman, rendahnya tingkat kekerasan masyarakat, perumahan yang terjangkau, akses kepusat-pusat rekreasi, udara dan air bersih, sekolah efektif, guru terlatih dan baik-kompensasi, program setelah sekolah, sumber rekreasi sekolah (olahraga, musik, seni), kesempatan pekerjaan untuk orang tua dan remaja, perawatan kesehatan masyarakat yang baik, akses kelayanan darurat (polisi, pemadam kebakaran, medis), koneksi kepembimbing dewasa yang peduli dan rekan-rekan pro-sosial. (4) Karakteristik budaya dan masyarakat; kebijakan perlindungan anak (pekerja anak, kesehatan anak, dan kesejahteraan), nilai dan sumber daya diarahkan pada pendidikan, pencegahan dan perlindungan dari penindasan atau kekerasan politik, penerimaan rendah kekerasan fisik ${ }^{24}$.

\section{Refleksi Implementasi Proses Diversi Dalam Penyelesaian Perkara Tindak Pidana Anak Di Indonesia}

UU No. 11 Tahun 2012 tentang Sistem Peradilan Pidana Anak (UU SPPA) lebih mengutamakan perdamaian dari pada proses hukum formal yaitu melalui diversi dan keadilan restoratif. Perubahan mendasar yang diinginkan dengan dilaksanakannya pendekatan keadilan restoratif (Restorative Justice) melalui sistem diversi adalah pengalihan penyelesaian perkara anak dari proses peradilan ke proses di luar peradilan pidana. Hal ini sejalan dngan apa yang disampaikan oleh Muladi Sistem peradilan Anak di Indonesia yang saat ini telah menjadi basis spirit di dalam RUU KUHP yang antara lain mengubah paradigma antara lain: Tujuan pemindanaan "penyelesaian konflik yang ditimbulkan oleh tindak pidana, memulihkan keseimbangan dan mendatangkan rasa damai masyarakat; semangat perhatian pada korban kejahatan;

${ }^{24}$ Masten, A. S., (2006)., Promoting resilience in development: A general framework for systems of care. In R. J. Flynn, P. M. Dudding, \& J. G. Barber (Eds.), Promoting resilience in child welfare (pp. 3-17). Ottawa, ON: University of Ottawa Press. 
pengembangan alternatif pidana kemerdekaan (alternative to imprisonment); pengaturan secara khusus pidana dan tindakan bagi anak. Selain dalam RUU KUHP juga pada UU SPPA yang telah meletakkan upaya diversi dan keadilan restoratif. ${ }^{25}$

Anak merupakan penerus generasi bangsa yang akan melanjutkan estafet kepemimpinan negara. Sebagaimana amanah UU No. 23 Tahun 2002 tentang Perlindungan Anak, anak adalah amanah dan karunia Tuhan Yang Maha Esa, yang dalam dirinya melekat harkat dan martabat sebagai manusia seutuhnya. Anak adalah tunas, potensi, dan generasi muda penerus cita-cita perjuangan bangsa, memiliki peran strategis dan mempunyai ciri dan sifat khusus yang menjamin kelangsungan eksistensi bangsa dan negara pada masa depan. Agar setiap anak kelak mampu memikul tanggung jawab tersebut, maka ia perlu mendapat kesempatan yang seluas-luasnya untuk tumbuh dan berkembang secara optimal, baik fisik, mental maupun sosial, dan berakhlak mulia, perlu dilakukan upaya perlindungan serta untuk mewujudkan kesejahteraan anak dengan memberikan jaminan terhadap pemenuhan hak-haknya serta adanya perlakuan tanpa diskriminasi. Untuk mencapai cita-cita tersebut, negara perlu memberikan perhatian khusus terhadap proses penyelesaian perkara pidana anak yang mengacu pada keadilan restoratif. Tujuan utama keadilan restoratif adalah untuk mereparasi kerugian korban, pengakuan pelaku atas kerugian akibat tindak pidana yang dilakukan, konsiliasi atau rekonsiliasi antara korban, pelaku dan masyarakat, reintegrasi pelaku dan melalui penyelesaian konflik secara damai (pecefully resolved) dapat dikelola keamanan masyarakat. ${ }^{26}$

Keadilan yang dimaksudkan di sini bukanlah keadilan yang berarti menjatuhkan hukuman yang sesuai tindakan si pelaku, melainkan suatu keadilan yang dikenal dengan keadilan restoratif.

\footnotetext{
25 Muladi, (2013)., Restorative Justice dalam Sistem Peradilan Pidana dan Implementasinya dalam Penyelesaian Tindak Pidana yang dilakukan oleh Anak-Anak (Jakarta: BPHN, 20 I3), hlm. 9-I I. 26 Muladi, (2013)., Restorative Justice dalam Sistem Peradilan Pidana dan Implementasinya dalam Penyelesaian Tindak Pidana yang dilakukan oleh Anak-Anak (Jakarta: BPHN, 20 I3), hlm. 9-I I.
} 
Keadilan restoratif adalah proses yang melibatkan secara bersamasama bagaimana mengatasi akibat dari suatu kejahatan yang implikasinya dimasa mendatang. Pendekatan keadilan restoratif merupakan proses keadilan yang sepenuhnya dijalankan dan dicapai oleh masyarakat ${ }^{27}$. Lebih lanjut dalam sistem peradilan anak (juvenile justice) harus mendayagunakan pendekatan keseimbangan (The Balanced Approach) yang dapat memenuhi kebutuhan masyarakat, bagi pelaku (anak-anak) yang setelah melalui proses restoratif diharapkan menjadi lebih mampu berintegrasi dengan masyarakat daripada sebelumnya; dan nilai perlindungan masyarakat (community protection), karena sistem keadilan restoratif bertanggungjawab untuk melindungi masyarakat dari tindak pidana anak-anak melalui cara-cara damai (peacefully resolved) ${ }^{28}$.

Keterlibatan korban, masyarakat yang terdampak dan pelaku, perlu pula ditekankan betapa pentingnya keterlibatan tenaga profesional yang terlatih dan yang memiliki keahlian khusus tentang perilaku remaja dalam proses keadilan restoratif (juvenile justice professional). Perannya antara lain: memfasilitasi mediasi, menentukan tempat-tempat tertentu yang berharga bagi masyarakat seandainya kewajiban pelayanan masyarakat (community service) harus dilakukan oleh pelaku, mengembangkan kelompok empati dan panel korban, mengorganisasikan panel; masyarakat, lembaga atau komite yang berdiskusi dengan pelaku untuk kepentingan korban, masyarakat dan pelaku, memfasilitasi proses permintaan maaf pelaku pada korban masyarakat, peningkatan kesadaran korban dan lain-lain ${ }^{29}$. Dukungan yang diberikan oleh berbagai pihak merupakan yang penting agar pelaku maupun korban anak-anak dapat melewati situasi tersebut, dapat belajar untuk menjadi pribadi yang lebih baik, dapat menata

\footnotetext{
27 Lilik Mulyadi, Sistem Peradilan Pidana Anak (Bandung:Alumni, 20 I4) hlm. 159.

${ }_{28}$ Muladi, (2013)., Restorative Justice dalam Sistem Peradilan Pidana dan Implementasinya dalam Penyelesaian Tindak Pidana yang dilakukan oleh Anak-Anak (Jakarta: BPHN, 20 I3), hlm. 9-I I. 29 Yul, Ernis., (2016)., Diversi Dan Keadilan Restoratif Dalam Penyelesaian Perkara Tindak Pidana Anak Di Indonesia (Diversion And Restorative Justice In Case Settlement Of Juvenile Justice System In Indonesia)., Jurnal IImiah Kebijakan Hukum., Volume I0, Nomor 2, Juli 2016
} 
kembali masa depannya, dan menjadi generasi harapan bangsa. Dukungan yang menguatkan dalam teori resiliensi disebut sebagai factor protektif, sedangkan factor yang melemahkan anak untuk mampu melewati situasi sulit disebut factor risiko.

Hasil penelitian ini menegaskan kembali mengenai pentingnya faktor protektif dan faktor risiko dalam membentuk resiliensi anak yang berkonflik dengan hukum. Fergus \& Zimmerman menyatakan bahwa persyaratan penting dari resiliensi adalah adanya faktor risiko dan faktor protektif yang membantu mempromosikan hasil positif atau mengurangi hasil negatif ${ }^{30}$, sedangkan menurut Masten \& Braswell, resiliensi dihambat oleh faktor-faktor risiko dan dipromosikan oleh faktor protektif. Faktor protektif mengubah respons terhadap kejadian buruk sehingga hasil negatif dapat dihindari $^{31}$. Di sisi lain, faktor risiko adalah keadaan yang meningkatkan kemungkinan hasil yang buruk. Menurut Shader (2003), beberapa penelitian telah menunjukkan bahwa adanya beberapa faktor risiko dapat meningkatkan kesempatan remaja terlibat dalam kenakalan, beberapa faktor protektif dapat bekerja untuk mengimbangi faktor risiko sehingga mengurangi kemungkinan kenakalan ${ }^{32}$.

Demikian halnya dengan Mykota \& Muhajarine menyatakan bahwa karakteristik individu, keluarga, dan masyarakat cenderung berkontribusi terhadap hasil resiliensi remaja. Pada tingkat individu termasuk jenis kelamin, harga diri yang positif, dan keterlibatan aktif dalam budaya seseorang. Pada tingkat keluarga mencakup struktur keluarga dan dukungan orangtua. Pada tingkat

\footnotetext{
30 Fergus, S. and Zimmerman, M.A. (2005) Adolescent resilience: A framework for understanding healthy development in the face of risk. Annual Review of Public Health, 26, 399-419.

31 Masten, A.S., \& Braswell, L. (1991). Developmental Psychopathology: An Integrative Framework. In P.R. Martin (Ed.), Handbook Of Behavior Therapy And Psychological Science: An Integrative Approach (pp. 35-56). Elmsford, NY: Pergamon Press .

32 Shader, M. (2003). Risk Factors Of Delinquency: An Overview. Washington, DC: U.S. Department of Justice, Office of Justice Programs, Office of Juvenile Justice and Delinquency Prevention.
} 
masyarakat terkait adanya dukungan komunitas yang positif ${ }^{33}$. Studi Howard dan Johnson menunjukkan bahwa faktor protektif berlaku di kehidupan remaja yang diidentifikasi sebagai remaja berrisiko. Faktor-faktor protektif terletak di dalam diri remaja (sikap belajar, kepercayaan) atau mereka dapat menemukan dalam konteks keluarga (orang dewasa yang peduli). Sekolah dan masyarakat juga dapat menjadi sumber faktor protektif (misalnya, sekolah yang mengajarkan untuk menguasai keilmuan, dan pemerintah yang menyediakan fasilitas rekreasi, dan kesempatan bagi remaja untuk bersosialisasi). Lebih banyak faktor protektif yang dapat dimobilisasi oleh remaja, semakin besar kemungkinan mereka untuk menampilkan perilaku resilien. Sebaliknya, semakin sedikit faktor protektif semakin besar kemungkinan remaja akan menunjukkan perilaku tidak resilien ${ }^{34}$.

Faktor protektif atau dukungan yang diberikan kepada anak yang berkonflik dengan hukum ketika menjalani proses hukum dapat berupa berbagai bentuk. Menurut Sarafino ada empat jenis dukungan sosial, yaitu (1) Emosional atau dukungan penghargaan (Emotional Or Esteem Support) menyampaikan empati, kepedulian, perhatian, penghargaan positif, dan dorongan terhadap orang tersebut. Ini memberikan kenyamanan dan kepastian dengan rasa memiliki dan dicintai pada saat stres. (2) Dukungan berwujud atau instrumental (Tangible or instrumental support) melibatkan bantuan langsung, seperti ketika orang memberi atau meminjamkan uang kepada orang tersebut atau membantu dengan tugas-tugas di saat stres. (3) Dukungan informasi (informational support) termasuk memberikan saran, arahan, saran, atau umpan balik tentang bagaimana orang tersebut melakukan. Misalnya, seseorang yang sakit mungkin mendapatkan informasi dari keluarga atau dokter tentang cara mengobati penyakitnya. (4) Dukungan persahabatan (Companionship support) mengacu pada ketersediaan orang lain

\footnotetext{
33 Mykota, D.B., \&Muhajarine , N., (2005)., Community Resilience Impact on Child and Youth Health Outcomes A Neighbourhood Case Study., Canadian Journal of School Psychology Volume 20 Number I/2 December 2005 5-20 (C) 2007 Sage Publications

${ }^{34}$ Howard, S, \& Johnson, B., (2000)., Resilient and Non-resilient Bahaviour in Adolescents., Trends \& Issue in Crime and Criminal Justice, No. 183 November 2000., Australia Institute of Crimiology.
} 
untuk menghabiskan waktu bersama orang tersebut, sehingga memberikan perasaan keanggotaan dalam sekelompok orang yang berbagi minat dan kegiatan sosial. Faktor risiko eksternal dalam penelitian ini meliputi kekerasan baik berupa kekerasan fisik maupun psikologis yang dialami oleh $\mathrm{ABH}$. Faktor risiko tersebut diperoleh dari keluarga, aparat penegak hukum (pemerintah), dan tetangga atau masyarakat. Faktor protektif internal merupakan meliputi karakteristik personal yang positif, yaitu yang cenderung mengembangkan pola adaptasi positif sehingga individu berhasil melewati situasi sulit yang dihadapi, sedangkan faktor protektif eksternal dapat berupa dukungan dari sekitar individu, yaitu keluarga, teman sebaya, tetangga, masyarakat, pemerintah, dan lembaga swadaya masyarakat.

Pentingnya factor protektif pada ABH selama menjalani proses hokum nampaknya belum berjalan sebagaimana yang dikonsepkan. Hal ini nampak pada perbedaan yang terjadi dari hasil penelitian ini. ABH yang resilien cenderung didukung oleh kuatnya factor protektif dan lemahnya factor risiko selama menjalani proses hokum, sebaliknya $\mathrm{ABH}$ yang tidak resilien cenderung kuat pada factor risiko dan lemah pada factor protektif. Untuk itu, untuk mencapai tujuan dilaksanakannya keadilan restorative dan diversi, perlu dikaji kembali pelaksanaan proses hukum pada $\mathrm{ABH}$. Keadilan restoratif dan diversi secara konseptual merupakan peradilan yang berbasis musyawarah dimana semua pihak yang terlibat dalam suatu tindak pidana tentu bersama-sama mengatasi masalah serta menciptakan suatu kewajiban untuk membuat segala sesuatunya menjadi lebih baik dengan melibatkan korban, anak, dan masyarakat dalam mencari suatu solusi untuk memperbaiki, rekonsiliasi, dan menenteramkan hati yang tidak berdasarkan pembalasan. Namun pada tataran implementasi anak tidak dilibatkan secara aktif dalam proses tersebut, anak kurang mendapatkan perhatian atas pemenuhanpemenuhan kebutuhannya sesuai dengan Undang-undang yang berlaku. 
Pendekatan keadilan restoratif menyediakan kesempatan dan kemungkinan bagi korban kejahatan untuk memperoleh reparasi, rasa aman, memungkinkan pelaku untuk memahami sebab dan akibat perilakunya dan bertanggungjawab dengan cara yang berarti dan memungkinkan masyarakat untuk memahami sebab utama terjadinya kejahatan, untuk memajukan kesejahteraan masyarakat dan mencegah kejahatan. Keadilan restoratif menampilkan serangkaian tindakan yang fleksibel yang dapat disesuaikan dengan sistem peradilan pidana yang berlaku dan secara komplementer dilakukan dengan mempertimbangkan kondisi hukum, sosial dan budaya. Pendayagunaan keadilan restoratif tidak akan merugikan hak negara untuk menuntut pelaku tindak pidana yang dicurigai ${ }^{35}$.

Proses diversi (pasal 8) dilakukan melalui musyawarah dengan melibatkan anak dan orang tua/Walinya, korban dan/atau orang tua Walinya, pembimbing kemasyarakatan, dan pekerja sosial profesional berdasarkan pendekatan keadilan restoratif (pasal 8 ayat (1)) dalam hal diperlukan, musyawarah dapat melibatkan tenaga kesejahteraan sosial, dan/atau masyarakat (pasal, 8 ayat (2)). Proses diversi wajib memperhatikan: 1) kepentingan korban; 2) kesejahteraan dan tanggung jawab anak; 3).penghindaran stigma negatif; 4). penghindaran pembalasan; 5.) keharmonisan masyarakat; dan 6) kepatutan, kesusilaan, dan ketertiban umum.

Dalam melakukan diversi penyidik, penuntut umum, dan hakim harus mempertimbangkan (pasal 9 (1\&2): 1) kategori tindak pidana (pasal 9 (1) huruf a), 2) umur anak (pasal 9 ayat (1) huruf b), 3) hasil penelitian kemasyarakatan dari bapas; dan 4) dukungan lingkungan keluarga dan masyarakat.

Selanjutnya kesepakatan diversi (kesepakatan antara pihak yang melibatkan anak dan orang tua/wali, korban dan atau orang tua/walinya, pembimbing kemasyarakatan, pekerja sosial

35 Muladi, (2013)., Restorative Justice dalam Sistem Peradilan Pidana dan Implementasinya dalam Penyelesaian Tindak Pidana yang dilakukan oleh Anak-Anak (Jakarta: BPHN, 20 I3), hlm. 9-II. 
profesional, perwakilan dan pihak-pihak yang terlibat lainnya) untuk menyelesaikan tindak pidana yang berupa pelanggaran, tindak pidana ringan, tindak pidana tanpa korban, atau nilai kerugian korban tidak lebih dari nilai upah minimum provinsi setempat sebagaimana dimaksud dalam pasal 9 ayat (2) diatas dapat dilakukan oleh penyidik bersama pelaku dan/atau keluarganya, pembimbing kemasyarakatan, serta dapat melibatkan tokoh masyarakat. Kesepakatan diversi dilakukan oleh penyidik atas rekomendasi pembimbing kemasyarakatan dapat berbentuk (Pasal 10 ayat (1\&2): 1) pengembalian kerugian dalam hal ada korban; 2) rehabilitas medis dan psikososial; 3) Penyerahan kembali kepada orang tua/Wali; 4) keikutsertakan dalam pendidikan atau pelatihan di lembaga pendidikan atau LPKS (Lembaga Penyelenggaraan Kesejahteraan Sosial) paling lama 3 (tiga) bulan; atau 5) pelayanan masyarakat paling lama 3 (tiga) bulan.

Bentuk hasil kesepakatan diversi, antara lain (pasal 11): 1) perdamaian dengan atau tanpa ganti kerugiaan; 2) penyerahan kembali kepada orang tua/Wali; 3) keikutsertaan dalam pendidikan atau pelatihan di lembaga pendidikan atau LPKS paling lama 3 (tiga) bulan; atau 4) pelayan masyarakat. Proses peradilan pidana Anak dilanjutkan dalam hal (Pasal 13): a. proses diversi tidak menghasilkan kesepakatan; atau b. kesepakatan diversi tidak dilaksanakan. Pasal 14 (1) pengawasan atas proses diversi dan pelaksanaan kesepakatan yang dihasilkan berada pada atasan langsung pejabat yang bertanggung jawab di setiap tingkat pemeriksaan. (2) selama proses diversi berlangsung sampai dengan kesepakatan diversi dilaksanakan, pembimbing kemasyarakatan wajib melakukan pendampingan, pembimbingan, dan pengawasan. (3) dalam hal kesepakatan diversi tidak dilaksanakan dalam waktu yang ditentukan, pembimbing kemasyarakatan segera melaporkannya kepada pejabat yang bertanggung jawab sebagaimana dimaksud pada ayat (1). (4) pejabat yang bertanggung jawab sebagaimana dimaksud pada ayat (3) wajib menindaklanjuti laporan dalam waktu paling lama 7 (tujuh) hari. 
Dengan demikian, diharapkan keadilan restorative dan diversi dapat diterapkan sesuai dengan peraturan perundang-undangan yang berlaku yang memiliki keberpihakan pada hak-hak anak, akan terhindarnya anak dari perlakuan yang justru dapat merugikan perkembangan Anak yang berhadapan dengan hukum atau sistem peradilan pidana anak. Tindak pidana anak yang akan datang dapat diselesaikan secara peradilan restoratif di mana permasalahan diselesaikan bersama antara anak yang terlibat, keluarga, dan pihak lain yang relevan dengan difasilitasi oleh petugas yang berorientasi pada perlindungan anak. Oleh karena itu, dalam penerapan keadilan restorative dan diversi perlu melibatkan berbagai pihak, termasuk tenaga ahli yang kompeten mengenai tumbuh kembang anak baik secara fisik maupun psikologi.

\section{Daftar Pustaka}

Astuti, M., (2011). Anak Berhadapan Dengan Hukum Ditinjau Dari Pola Asuhnya Dalam keluarga (Studi Kasus Di Provinsi Sumatera Barat, Daerah Istimewa Jogyakarta Dan Provinsi Nusa Tenggara Barat)., Jurnal Informasi Kajian Permasalahan Sosial Dan Usaha Kesejahteraan Sosial Vol. 16, No. 01, Januari April 2011

Fergus, S. and Zimmerman, M.A. (2005) Adolescent resilience: A framework for understanding healthy development in the face of risk. Annual Review of Public Health, 26, 399-419.

Garmezy, N. (1993). Children in poverty: Resiliency despite risk. Psychiatry, 56(1), 127-136.

Grotberg, E.H. (1999). Countering Depression With the Five Building Blocks of Resilience. From: Grotberg, Edith. (1999). Countering depression with the five building blocks of resilience. Reaching Today's Youth 4(1, Fall): 66-72. http://resilnet.uiuc.edu/library/grotb99.html

Howard, S, \& Johnson, B., (2000)., Resilient and Non-resilient Bahaviour in Adolescents., Trends $\mathcal{E}$ Issue in Crime and 
Criminal Justice, No. 183 November 2000., Australia Institute of Crimiology.

Hurlock, E. B. (2011). Psikologi Perkembangan Suatu Pendekatan Sepanjang Rentang Kehidupan, Edisi 5. Jakarta: Erlangga.

Kartono, Kartini., (2003). Patologi Sosial 2. Kenakalan Remaja. Jakarta: PT Raja Grafindo Persada

Kumpfer, K. L., (1999).,Factors and Processes Contributing to Resilience. In. The Resilience Framework Resilience and Development: Positive Life Adaptations, 1999. edited by Glantz and Johnson. Kluwer Academic/Pienum Publishers, New York,

Lilik Mulyadi, Sistem Peradilan Pidana Anak (Bandung:Alumni, 2014) hlm. 159.

Luthar, S. S., Cicchetti, D., \& Becker, B., (2000)., The construct of resilience: A critical evaluation and guidelines for future work. Child Development, 71, 543-562.

Masten, A. S., (2006)., Promoting resilience in development: A general framework for systems of care. In R. J. Flynn, P. M. Dudding, \& J. G. Barber (Eds.), Promoting resilience in child welfare (pp. 3-17). Ottawa, ON: University of Ottawa Press.

Masten, A. S., Best, K. M. \& Garmezy, N., (1990)., Resilience and development: Contributions from the study of children who overcome adversity. Development and Psychopathology, 2, 425444.

Masten, A.S., \& Braswell, L. (1991). Developmental Psychopathology: An Integrative Framework. In P.R. Martin (Ed.), Handbook Of Behavior Therapy And Psychological Science: An Integrative Approach (pp. 35-56). Elmsford, NY: Pergamon Press .

Masten, A.S., 1994., Resilience In Individual Development: Successful Adaptation Despite Risk And Adversity. In M. Wang \& E. Gordon (Eds.), Risk and resilience in inner city America: challenges and prospects. (pp. 3-25). Hillsdale, NJ: Erlbaum. 
McCubbin, L., (2001).,Challenges to the Definition of Resilience., American Psychological Association. Paper presented at the Annual Meeting of the American Psychological Association (109th, San Francisco, CA, August24-28, 2001).

Monk, F.J., Knoers, A.M.P., Haditono, S.R. (2011). Psikologi Perkembangan. Pengantar dalam Berbagai Bagiannya. Jogjakarta: Gadjah MadaUniversity Press.

Muladi, (2013)., Restorative Justice dalam Sistem Peradilan Pidana dan Implementasinya dalam Penyelesaian Tindak Pidana yang dilakukan oleh Anak-Anak (Jakarta: BPHN, 2013), hlm. 9-11.

Mykota, D.B., \&Muhajarine , N., (2005)., Community Resilience Impact on Child and Youth Health Outcomes A Neighbourhood Case Study., Canadian Journal of School PsychologyVolume 20 Number 1/2 December 2005 5-20 @ 2007 Sage Publications

Reivich, K. \& Shatte,A., (2002)., The resilience faktor:Seven essential skills for overcoming life's inevitable obstacles. New York:Broadway Books

Reivich, K. \&Shatte,A., (2002)., The resilience faktor:Seven essential skills for overcoming life's inevitable obstacles. New York:Broadway Books

Sarwono, S. W. (2012)., Psikologi Remaja. Edisi revisi 15. Jakarta: Raja Grafindo Pustaka,

Schoon, I. \& Bynner, J. (2003). Risk and resilience in the life course: Implications for interventions and sosial policies. Journal of Youth Studies, 6(1), 21-31.

Shader, M. (2003). Risk Factors Of Delinquency: An Overview. Washington, DC: U.S. Department of Justice, Office of Justice Programs, Office of Juvenile Justice and Delinquency Prevention.

Sudarsono.,(1991)., Kenakalan Remaja., Jakarta: RinekaCipta

Supeno, H., (2010)., Kriminalisasi Anak. Tawaran Gagasan Radikal Peradilan Anak Tanpa Pemidanaan., PT. Gramedia Pusaka Utama 
Undang-Undang RI Nomor 11 Tahun 2012 tentang Sistem Peradilan Pidana Anak

UU No.11 Tahun 2012 tentang Sistem Peradilan Pidana Anak

UU No.23 Tahun 2002 Tentang Perlindungan Anak

Werner, E. E. (2005). What can we learn about resilience from largescale longitudinal studies? In S. Goldstein \& R. Brooks (Eds.), Handbook Of Resiliencein Children (pp. 91 - 106). New York: Kluwer Academic Publishers.

www.kpai.co.id

Yul, Ernis., (2016)., Diversi Dan Keadilan Restoratif Dalam Penyelesaian Perkara Tindak Pidana Anak Di Indonesia (Diversion And Restorative Justice In Case Settlement Of Juvenile Justice System In Indonesia)., Jurnal Ilmiah Kebijakan Hukum., Volume 10, Nomor 2, Juli 2016 